Bern aus dem Jahr 1912. Pp. xlvi $+349+3$ plates. (Bern : K. J. Wyss.)

Ministère de l'Agriculture. Direction Générale des Eaux et Forêts. $2^{\mathrm{e}}$ Partie. Eaux et Améliorations Agricoles. Service des Grandes Forces Hydrauliques dans la Région des Alpes. Tome v. Résultats des Etudes et Travaux à la Fin de rgir. Pp. 530. (Publisher's name not given.)

A Course of Elementary Workshop Drawing. By H. A. Darling. Pp. vi +172 . (London: Blackie and Son, Ltd.) Is. $6 d$.

The Origin and Antiquity of Man. By Dr. G. F. Wright. $\mathrm{Pp} . \mathrm{xx}+547$. (London: J. Murray.) $8 \mathrm{~s}$. net.

The Important Timber Trees of the United States. By S. B. Elliott. Pp. xix +382 . (London: Constable and Co., Ltd.) Ios. $6 d$. net.

The Potato. By E. H. Grubb and W. S. Guilford. Pp. 545. (London : Constable and Co., Ltd.) 8s. $6 d$. net.

Handbuch der Arbeitsmethoden in der anorganischen Chemie. By Dr. A. Stähler. Erster Band. Pp. xii + 786. (Leipzig: Veit and Co.) 25 marks.

Annales de l'Observatoire National d'Athènes. By Prof. D. Eginitis. Tome vi. Pp. 333+plates. (Athens: A. Raftanis.)

Abel's Laboratory Handbook of Bacteriology. Second English Edition. By Dr. M. H. Gordon and others. Pp. xi+25I. (London: H. Frowde and Hodder and Stoughton.) 5s. net.

Missouri Botanical Garden. Twenty-third Annual Report. Pp. $207+7$ plates. (St. Louis, Mo.: The Board of Trustees.)

L'Uomo Attuale una Specie Collettiva. By V. Giuffrida-Ruggeri. Pp. viii $+192+x$ iii plates. (Mílan : Albrighi, Segati e. C.) 6 lire.

Mitteilungen aus den deutschen Schutzgebieten. Edited by Dr. H. Marquardsen. Ergänzungsheft, Nr. 6, Ergebnisse einer Reise durch das Zwischenseengebiet Ostafrikas r9I I. By H. Meyer. Pp. iii + I27+ viii plates. (Berlin : E. Siegfried Mittler und Sohn.) 3.60 marks.

Die antike Tierwelt. By O. Keller. Zweiter Band. Pp. $x v+618+2$ plates. (Leipzig: W. Engelmann.) I7 marks.

The Continents and Their People. Asia : a Supplementary Geography. Bv J. F. and A. H. Chamberlain. Pp. vit 198. (London: Macmillan and Co., Itd.) $3 s$.

\section{DIARV OF SOCIETIES.}

THUR.SDAY. APRIL I7.

Roval Society, at $4 \cdot 30$. - The Tuminosity Curves of Persons having Normal and Abnormal Colnur Vis:on: Dr. W. Watson.-The Reflection of X-Rays by Crystals: Prof W. H. Bragg and W. L. Bragg.-A X-Rays by Crys'als: Prof W. H. Bragg and W. L. Bragg.-A
Fluorescence Srectrum of Iodine Vapour: Prof. I. C. McLennan.-The Relation between the Crystal-symmetry of the Simpler. Organic Com. Relation between the rry-tal-symmetry of the Simpler. Or pounds and their Molecular Const'tution. 1.: Dr. W. Wahl.
Roval. Institurion, at 2.-The Progress of Hittite Studies. I. Recent
Explorations: Prof, J. Garstang.

InStitution of Mining AND METAliurgy, at 8.-- Notes on Some Bulgarian Mineral Deposits: H. K. Srott.-Notes on the San Francisco Mill, Pachuca, Mexico: J. P. Holcombe-Errors in Samp
Assaying Ores dise to the Presence of Coarse Gold : F. White.

Assaying Ores dise to the Presence of Coarse Gold : F. White.
Royal Society of Arts, at 430 . - The Burma Oil Fields: N. G. Cholmeley.

Royal Society of Arts, a' 4 30.-The Burma Oil Fields: N. G. Cholmeley.
Linnean Society, at 8.-An Arcount of the Plants Collected by Mr. M. P.

Linnean Society, at 8.-An Arcount of the Plants Collected by Mr. M. P
Price on the Carruther--Miller-Price Expedition through North-west Mongolia and Chinese Dzungaria: M. P. Prire and N. D. Simpson.The Flora of the Island of Shikotan: Hisayoshi Takeda.

$$
\text { FRIDAY, APRIL } 18 .
$$

Roval Institution, at $9 .-$ Applications of Polarised Light : Dr. T. M. Lowry.

InSTITUtion of Mechanical. FNGineERs, at 8.-Presidential Address. Discussion: Volute Chambers and Guide-passages for Centrifugal Pumps : Prof. Gibson. MONDAY. APRIL ?I.

Royal Society of Arts, at 8.-Antiseptics and Disinfectants. I. : Dr. D.

Sommerville.
VICTORIA INSTITUTE, at 4.30.-The Samaritan Pentateuch, and Philological Questions connected therewith: Rev. J. I. Munro.

Institution of Civil. Engrneers, at 8. -Production of Steel Sections and their Application in Engineering Structures : A. T. Walmisley. No. 2268 , VOL. 9I]
TUESDAY, APRIL 22.

Royal Institution, at $3 .-$ The Heredity of Sex and Some Cognate Problems. II. : Prof.

ROVAL ANTHROPOLOGICAL INSTITUTE, at 8.15.-The Weeping God T. A. Joyce.-Prehistoric and Other Antiquities in the Departments $t$ Vienne and Charente, France: A. L. Lewis.

Institution of Civil Engineers, at 8.--Assuan Dam: Protection of Down-stream Rock Surface, and Thickening and Heightening: $M$. Macdonald.

Zoological Society, at 8.30.-The Polyzoa of Waterworks: Dr. S. F. Harmer.-The Marine Fauna of British East Africa and Zanzibar, from Collections made by Cyril Crossland, in the Years rgor-2. BryozoaCheilostomata: A. W. Waters.-Notes on Albinism in the Common Reedbuck (Cervicapra arundinum), and on the Habits and Geographical Distribution of Sharpe's Steenbuck (Raphiceros sharpei): Major J. Stevenson-Hamilton.

WEDNESDAY, APRIL 23.

Roval Society of Arts, at 8.-The Design and Architectural Treatment of Shops: H. V. Lanchester.

Grological Society, at 8.--The Fossil Flora of the Pembrokeshire Portion of the South Wales Coalfield: H. Goode.-The Halesowen Sandstone Series of the Southern End of the Soutb Staffordshire Coalfield: H. Kay. Aëronautical Society, at 8.30.-Aëroplane Construction: A. R. Low.

\section{THURSDAY, APRIL, 24 .}

Royal Society, at 4.30.-Probable Papers: (I) Protostigmata in Ascidians (2) The Origin of the Ascidian Mouth:A. G. Huntsman.-Experiments on the Kidneys of the Frog: F. A. Bainbridge, S. H. Collins, and J. A. Menzies. -(x) The Probable Value to $B$. coli of "Slime" Formation in Soils ; (2) Variation in $B$. coli. The Production of Two Permanent Varieties from One Original Strain by Means of Brilliant Green : Cecil Revis.

Royal. Institution, at 3. - The Progress of Hittite Studies. II. Religious Monuments of Asia Minor: Prof. J. Garstang.

Monuments of Asia Minor: Prof. Garstang.
Society OF Dyers AND Colourists (London Secrion), at 8.-The ChemOCIETY OF DYERS AND COLOURISTS (Lon

istry of the Vat Dies: E. A. Barnett.

G. Kapp.
CONCRFTF. INSTITUTE, at 7.30.-Discussion on Reports of the Science StandCONCRFTF. INSTITUTE, at 7.30.-Discussion on Reports of the Science Stand
ing Committee on : ( $\mathrm{r}$ ) A Standard Notation for Structural Engineering Calculations : (2) A Standard Specification for. Reinforced Concrete Work ; (3) Standard Connections and Joints in Reinforced Concrete.

\section{CONTENTS.}

PAGE

A Text-book of Human Physiology . . . . . . . I57

Typical Ammonites ............ . 157

Topography and Travel ........... . 158

\section{Our Bookshelf}

Letters to the Editor:-

Soil Fertility:-F. Fletcher ; Dr. E. J. Russell . . 160

Induced Cell-reproduction in the Protozoa.-Aubrey H. Drew

Units of Pressure in Vacuum Work-W. W. Keesom Reflection of X-Rays and X-Ray Fringes. (With Diagram.) $M$. de Broglie . . . . .

Increase of Definition in a Moving Telescope.-
M. E. J. Gheury . . . . . . . . 162 The Ninth International Congress of Zoology at

Monaco ............ I62 The International Congress of Historical Studies I65 Public Veterinary Services . . . . . . . . . 166 Notes Our Astronomical Column :-

The Question of Radium in the Chromosphere . . . I71 Dedication of the New Allegheny Observatory . . . 171 General Index to the Memoirs of the Society of Italian Spectroscopists - i d Prof $\mathrm{R}$ A National Aspects of Education. By Prof. R. A.
Gregory Garegory in Atmospheric Circulation in Tem. perate Latitudes. By E. Gold . . . . . . . I74 Gyrostats and Gyrostatic Action. (Illustrated.) By Prof. Andrew Gray, F.R.S. . . . . . . . . . . . 175

University and Educational Intelligence. . . . . 179

Societies and Academies . . . . . . . . . I80

Books Received . . . . . . . . . . . $18 \mathrm{r}$

Diary of Societies . . . . . . . . . . . 182

\section{Editorial and Publishing Offices:}

MACMILLAN \& CO., LTD.

ST. MARTIN'S STREET, LONDON, W.C.

Advertisements and business letters to be addressed to the Publishers.

Editorial Communications to the Editor.

Telegraphic Address: Phusis, Londun.

Telephone Number: GERRARD 8830. 